\title{
Pengaruh Pengetahuan,Kemudahan dan Risiko Terhadap Minat Bertransaksi Menggunakan Finansial Technology (Fintech) Pada Mahasiswa Institut Agama Islam Negeri (IAIN) Palu
}

\author{
Nurdin Nurdin ${ }^{*}$, Winda Nur Azizah ${ }^{2}$, Rusli Rusli ${ }^{3}$ \\ 1 Perbankan Syariah, Fakultas Ekonomi dan Bisnis Islam, IAIN Palu, nnurdin@iainpalu.ac.id \\ 2 Perbankan Syariah, Fakultas Ekonomi dan Bisnis Islam, IAINPalu \\ ${ }^{3}$ Pascasarjana, IAIN Palu, rusli@iainpalu.ac.id
}

\section{ABSTRAK}

Penelitian ini bertujuan untuk mengetahui pengaruh pengetahuan, kemudahan dan risiko terhadap minat bertransaksi menggunakan Financial Technology pada mahasiswa Institut Agama Islam Negeri (IAIN) Palu. Penelitian ini menggunakan pendekatan kuantitatif. Populasi dalam penelitian ini adalah mahasiswa Institut Agama Islam Negeri Palu (IAIN) Palu. Teknik pengambilan sampel yang digunakan adalah teknik proporsional stratified random sampling sebanyak 98 orang, dengan menggunakan rumus slovin untuk menentukan jumlah sampel. Teknik pengumpulan data adalah melalui teknik kuesioner dan wawancara. Dan teknik analisa yang digunakan adalah analisis regresi linear berganda. Hasil penelitian ini menunjukkan bahwa variabel pengetahuan memiliki nilai signifikan $\mathrm{t}$ hitung sebesar 0,330 . Hal ini menunjukkan bahwa pengetahuan tidak berpengaruh terhadap minat bertransaksi menggunakan Fintech. Dari hasl uji statistik t pada kemudahan nilai signifikan $\mathrm{t}$ hitung lebih kecil dari $0,05(0,22<0,05)$. Kemudahan penggunaan berpengaruh positif dan signifikan terhadap minat bertransaksi menggunakan Fintech. Dari hasil uji statistik t pada variabel risiko nilai siignifikansi tehitung lebih kecil dari 0,05 dan koefisien regresi sebesar 3.828. Risiko memiliki nilai signifikansi thitung sebesar 0,000 .Nilai t negatif menunjukan bahwa variabel risiko berpengaruh terhadap minat bertransaksi menggunakan Fintech.
INFORMASI

ARTIKEL

Katakunci:

Fintech, Pengetahuan, kemudahan, resiko, transaksi, minat 


\section{Pendahuluan}

Menurut hasil survei yang dilakukan oleh Asosiasi Penyelengga Jasa Internet Indonesia (APJII) bahwa pengguna Internet di indonesia sebanyak 171,17 juta jiwa atau sebesar $64,8 \%$ dari total penduduk indonesia sebesar 246,16 juta jiwa adalah pengguna Internet. ${ }^{1}$ Perkembangan teknologi digital sekarang sudah merambah hampir seluruh aspek kehidupan mulai dari berbelanja, transportasi, keuangan, pariwisata hingga memberikan donasi serta kegiatan ekonomi lainnya dapat diakses secara digital. Perkembangan Teknologi digital telah mengubah gaya hidup masyarakat masa kini, kehidupan masyarakat yang dekat dengan gadget dan Internet dan di dukung dengan fasilitas pelayanan yang berbasis teknologi digital membuat aktivitas sehari-hari masyarakat menjadi lebih sederhana dengan menggunakan gadget dalam genggaman tangan mereka. Hal ini mendorong perkembangan bi berbasis teknologi digital, salah satu adalah Financial Technology (Fintech). Kehadiran teknologi finansial sangat membantu masyarakat dalam mengakses produk-produk keuangan dan mempermudah melakukan transaksi keuangan dengan sentuhan teknologi di tangan. Dimanapun dan kapanpun masyarakat dapat melakukan transaksi tanpa harus datang ke perusahaan finansial atau mengantri dengan berbagai prosedur seperti perbankan pada umumnya. Hal ini

1 Penetrasi Pengguna Internet, Situs Asosiasi Penyelenggara Jasa Internet Indonesia. Website: htps://www.apji.or.id (diakses 29 September 2019) dapat meningkatkan literasi keuangan di Indonesia.

Teknologi finansial (Financial Technology) disingkat atau disebut dengan TekFin atau Fintech. Teknologi Finansial dalam peraturan Bank Indonesia Nomor 19/12/PBI/2017 merupakan penggunaan teknologi sistem keuangan yang menghasilkan produk, layanan, teknologi, dan/atau model bisnis baru serta dapat berdampak pada stabilitas moneter, stabilitas sistem keuangan, efesiensi, kelancaran, kemananan dan keandalan sistem pembayaran. ${ }^{2}$ Penyelenggara teknologi finansial yakni meliputi sistem pembayaran, pendukung pasar, manajemen investasi dan manajemen risiko, pinjaman, pembiayaan dan penyedia modal, dan jasa finansial lainnya. ${ }^{3}$

Saat ini di Indonesia terdapat 127 perusahaan yang telaha berizin dan terdaftar di Otoritas Jasa Keuangan (OJK) per tanggal 30 September 2019.4 Jumlah perusahaan yang menyelenggarakan Fintech masih terus bertambah setiap tahunnya, hal ini terbukti dari data yang diunggah oleh OJK bahwasannya jumlah perusahaan Fintech baik yang sudah terdaftar atau yang masih proses pendaftaran terus mengalami peningkatan. Hal ini

2 Marzuki, M., \& Nurdin, N. (2020). The Influence of Halal Product Expectation, Social Environment, and Fiqih Knowledge on Intention to Use Shariah Financial Technology Products. International Journal of Innovation, Creativity and Change, 13(1), 171-193.

3 Peraturan Bank Indonesia, Situs Bank Indonesia. Website: https://www.bi.go.id (diakses 22 Juni 2020)

${ }^{4}$ Financial Technology, Situs Otoritas Jasa Keuangan. Website: https://www.ojk.go.id (diakses 30 September 2019)

e-ISSN: 2686-6633 
merupakan suatu hal yang positif karena dengan semakin banyak perusahaan yang mempunyai izin operasional di harapkan dapat memberikan kenyamanan kepada masyarakat dalam menggunakan jasa layanan keuangan berbasis teknologi digital. Dalam hal ini pihak yang berwenang dalam mengatur operasional Fintech adalah Bank Indonesia (BI), Otoritas Jasa Keuangan (OJK), dan Kementrian Komunikasi dan Informasi (KEMKOMINFO). Regulasi dari pihak berwenang sangat bermanfaat bagi konsumen sehingga hak- hak konsumen dapat terlindungi sehingga konsumen mendapat kenyamanan saat bertransaksi.

Indonesia sangat berpotensi dalam pengembangan Fintech melihat sudah banyaknya produk-produk baru yang bermunculan dan didukung besarnya pengguna internet yang sangat besar di Indonesia. Di Indonesia industri Fintech didominasi oleh sektor Payment sebesar 38\%, Lending sebesar 31\%, Personal Finance and Wealth Management sebesar $8 \%$ dan sisanya diisi oleh sektor lainnya. ${ }^{5}$ Sektor pembayaran saat ini masih menguasai pasar Fintech di Indonesia dan menjadi primadona masyarakat masa kini. Fintech perlu dibudidayakan di lingkungan kampus, namun hanya sedikit kampus yang memanfaatkan Fintech untuk mempermudah akses di kampus, baik mahasiswa, dosen dan kegiatan akademik lainnya. ${ }^{6}$ berdasarkan

\footnotetext{
${ }^{5}$ Muhammad Wildan, "Pengaruh Persepsi Kemudahan, Efektivitas dan Risiko Terhadap Minat Menggunakan Fintech".Skripsi FEBI UIN Walisongo Semrang.2018.

https://www.unisba.ac.id/index.php/en/illust
}

wawancara awal yang dilakukan oleh peneliti terhadap mahasiswa Institut Agama Islam Negeri Palu bahwasannya 4 dari 10 orang mahasiswa menggunakan produk layanan pembayaran digital seperti, OVO, Go Pay, Grab Pay, T-cash, Shopee Pay dan lain-lain.

Hadirnya sebuah inovasi teknologi ditujukan agar memudahkan aktivitas setiap indiviu, hal ini ditujukan agar produktivitas setiap individu meningkat. Dengan ditawarkan berbagai macam kemudahan dan manfaat serta berbagai fitur yang lengkap di setiap produknya bertujuan agar menarik lebih banyak penggguna. Namun dalam hal ini tidak seluruh lapisan masyarakat mencoba beradaptasi dengan menggunakan layanan berbasis Teknologi Informasi dan meninggalkan layanan konvensional. Dari sekian banyak pengguna internet di Indonesia hanya $7,39 \%$ yang menggunakan layanan internet untuk mengakses layanan keuangan. ${ }^{7}$ Meskipun banyak kemudahan dan fitur lengkap yang ditawarkan dalam produk Fintech, berdasarkan wawancara peneliti pada mahasiswa Institut Agama Islam Negeri Palu 6 dari 10 orang mahasiswa Institut Agama Islam Negeri Palu belum menggunakan Fintech. Hal ini menunjukkan bahwa penawaran yang dilakukan oleh perusahaan belum bisa meningkatkan permintaan dikalangan

rations/item/480-367-peserta-ikuti-snapp- 2017 2-rektor-budayakan-Fintech-di-kampus (di akses pada 29 september 2019)

7 Penetrasi Pengguna Internet, Situs Asosiasi Penyelenggara Jasa Internet Indonesia. Website : https.apjii.or.id (diakses 29 September 2019) 
mahasiswa IAIN Palu. Dengan demikian bisa menjadi bahan evaluasi bagi perusahaan untuk menawarkan produk Fintech yang sesuai dengan kebutuhan mahasiswa.

Pengetahuan dapat diartikan sebagai hasil keingintahuan, segala perbuatan atau usaha manusia untuk memahami obyek yang dihadapinya. Pengetahuan dapat berwujud barangbarang fisik yang pemahamannya dilakukan dengan cara persepsi, baik melalui panca indera maupun akal. ${ }^{8}$ Pengetahuan pada hakikatnya meliputi semua yang diketahui seseorang terhadap objek tertentu..$^{9}$ Secara umum hal yang paling mendasari untuk mengembangkan suatu teknologi terhadap mahasiswa IAIN Palu yaitu pengetahuan. Timbulnya pengetahuan individu cenderung diperoleh dari adanya pengalaman dari beragam sumber seperti media elektronik, buku panduan, media poster dan sebagainya. berdasarkan wawancara peneliti pada mahasiswa Institut Agama Islam Negeri Palu 6 dari 10 mahasiswa IAIN Palu belum mengetahui produk-produk apa saja yang ditawarkan Financial Technology (Fintech).

Kemudahan berarti keyakinan individu bahwa menggunakan sistem teknologi informasi tidak akan merepotkan atau membutuhkan usaha

8 Nurdin, N., \& Yusuf, K. (2020). Knowledge management lifecycle in Islamic bank: the case of syariah banks in Indonesia. International Journal of Knowledge Management Studies, $\quad 11(1)$, 59-80. https:// doi.org/10.1504/ijkms.2020.105073

9I Made Wirartha, Metodologi Penelitian Sosial Ekonomi, Ed. 1, Yogyakarta: ANDI, 2006, hlm. 1. yang besar pada saat digunakan. ${ }^{10}$ Setiap teknologi diciptakan guna mempermudah aktivitas setiap individu, semakin mudah teknologi maka individu semakin berminat menggunakannya. Menurut wawancara peneliti 6 dari 10 mahasiswa IAIN Palu pengguna produk Fintech merasa kesulitan dalam menggunakan aplikasi dari produk Fintech, meskipun dalam aplikasi produk Fintech telah dilengkapi tatacara penggunaanya. Hal ini juga yang menjadi alasan dari mahasiswa yang belum menggunakan produk Fintech, karena dianggap betransaksi menggunaka Fintech lebih sulit dari bertransaksi secara langsung. Hal ini bukan tanpa alasan, mahasiswa IAIN Palu tidak mengoptimalkan fungsi dari smartphone atau gadget yang dimilikinya, kebanyakan smartphone mahasiswa IAIN Palu digunakan untuk mengakses social media, game dan aplikasi hiburan lainnya. Seperti yang kita ketahui banyak aplikasi yang bermanfaat bagi kehidupan sehari-hari namun jarang sekali digunakan oleh mahasiswa, seperti Microsoft Office, Gmail, Note dan lain-lain. Seharusnya penggunaan teknologi perlu dibiasakan sehingga ketika ada inovasi baru kita sebagai pengguna sudah terbiasa dengan kehidupan digital dan tidak mengalami kesulitan terhadap pengoperasiannya.

Risiko merupakan suatu ketidakpastian yang dirasakan oleh

10 Andriyanto, Yaufi. "Pengaruh Persepsi Kemudahan, Persepsi Kebermanfaatan, Persepsi Risiko dan Kepercayaan Terhadap Minat Menggunakan Rekening Ponsel (Studi Kasus Pada Nasabah CIMB NIAGA Daerah Istimewa Yogyakarta)".Skripsi.Fakultas Ekonomi Universitas Negeri Yogyakarta.2014. h.43.

e-ISSN: 2686-6633 
pengguna yang menimbulkan kerugian kepada pengguna. Risiko yang awal dirasakan oleh pengguna adalah risiko kejahatan cyber (cyber risk). ${ }^{11}$ Kejahatan cyber dapat mengancam setiap transaksi yang dilakukan konsumen, keamanan data pribadi setiap pengguna juga tidak luput dari ancaman kejahatan cyber. Kebocoran data pribadi dan penyalahgunaan data dapat merugikan penguna. Bisnis Fintech merupakan bisnis kepercayaan antara pengguna dan pengembang, jika terjadi sebuah kebocoran data, penyalahgunaan data, pemalsuan data dan sebagainya sama sajamenciderai kepercayaan antara pengguna dan pengembang dan sebaliknya. Kepercayaan sangatlah penting dalam hal ini dimana pengguna dan pengembang Fintech tidak dipertemukan secara langsung, karena penggunaan Fintech dilakukan dengan jarak jauh. Setiap risiko tentunya dapat diminimalisir dengan kebijakankebijakan yang saling menguntungkan antara kedua belah pihak sehingga tidak menimbulkan kerugian-kerugian yang berarti diantara kedua belah pihak. Sebagian Mahasiswa IAIN Palu yang telah menggunakan produk Fintech tidak terlalu mengkhawatirkan risiko yang ada dalam penggunaan poduk Fintech. Mereka tetap akan mengunakan produk meskipun berisiko.

\section{Tinjauan Pustaka}

\subsection{Pengertian Pengetahuan}

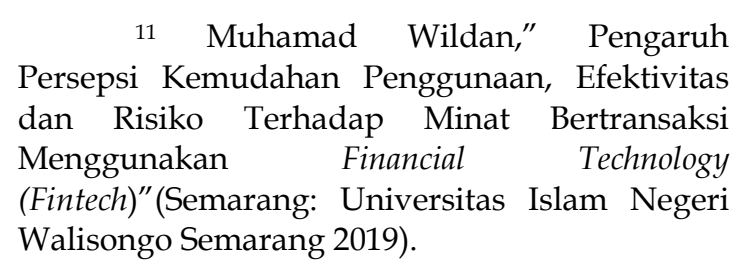

Secara etimologi pengetahuan berasal dari kata dalam Bahasa Inggris yaitu knowledge.12,13 Secara sederhana, pengetahuan adalah segala sesuatu yang ada di kepala kita. ${ }^{14}$ Menurut Kamus Besar Bahasa Indonesia, pengetahuan adalah segala sesuatu yang diketahui (kepandaian) yang berhubungan dengan hal (mata pelajaran). ${ }^{15}$ Sedangkan menurut Notoadmodjo adalah hasil penginderaan manusia, atau hasil tahu seseorang terhadap objek melalui indera yang dimilikinya (mata, hidung, telinga, dan sebagainya). Menurut Notoatmodjo, pengetahuan seseorang terhadap objek mempunyai intensitas atau tingkat yang berbeda beda.

1) Tahu (know)

Diartikan hanya sebagai recall (memanggil) memori yang telah ada sebelumnya setelah mengamati sesuatu. Untuk mengetahui atau mengukur bahwa orang tahu sesuatu dapat menggunakan pertanyaan-pertanyaan.

2) Memahami (comprehension)

Memahami suatu objek bukan sekedar tahu tehadap objek tersebut,

12 Kimberly Adams dan A.A Waskito, Kamus Bahasa Inggris-Indonesia. (Jakarta: Wahyumedia, 2016), 119.

13 Nurdin, N. (2019). Knowledge Integration Strategy in Islamic Banks. In A. Helena \& S. Bernardete (Eds.), The Role of Knowledge Transfer in Open Innovation (pp. 118138). IGI Global. https:// doi.org/10.4018/978-15225-5849-1.ch006

14 Bambang Prasetyo dan Lina Miftahul Jannah, Metode Penelitian Kuantitatif : Teori dan Aplikasi, Ed 1,(Jakarta : PT Raja Grafindo Persada,2006),hlm 3.

15 Tim Redaksi, Kamus Besar Bahasa Indonesia Pusat Bahasa, Ed 4, Jakarta : PT Gramedia Pustaka Utama, Cet.ke,2008, hlm 1.377.

e-ISSN: 2686-6633 
tidak sekedar dapat menyebutkan, tetapi orang tersebut harus dapat menginterprestasikan secara benar tentang objek yang diketahui tersebut.

3) Aplikasi (aplication)

Aplikasi diartikan apabila orang yang telah memahami objek yang dimaksud dapat mengguunakan atau mengaplikasikan prinsip yang diketahui tersebut pada situasi yang lain.

4) Analisa (analisys)

Analisis adalah kemampuan seseorang untuk menjabarkan dan/atau memisahkan, kemudian mencari hubungan antara komponen-komponen yang terdapat dalam suatu masalah atau objek yang diketahui.

5) Sintesis (synthesis)

Sintesis menunjukkan suatu kemampuan seseorang untuk merangkum atau meletakkan dalam satu hubungan yang logis dari komponen-komponen pengetahuan yang dimiliki.

\section{6) Evaluasi (evaluation)}

Evaluasi berkaitan dengan

kemampuan seseorang untuk melakukan justifikasi atau penilaian terhadap suatu objek tertentu. ${ }^{16}$

Pengetahuan dapat diartikan sebagai hasil keingintahuan, segala perbuatan atau usaha manusia untuk memahami obyek yang dihadapinya. Pengetahuan dapat berwujud barangbarang fisik yang pemahamannya dilakukan dengan cara persepsi, baik melalui panca indera maupun akal. Pengetahuan pada hakikatnya meliputi

\footnotetext{
16Soekidjo, Notoadmodjo, Metode Penelitian Kesehatan, edisi revisi, Jakarta : Rinneka cipta, 2010.
}

semua yang diketahui seseorang terhadap objek tertentu.

Menurut Saefuddin Ansari Dikutip dalam Muhammad Nurdin ,pengetahuan dapat dibedakan menjadi empat macam, yaitu ${ }^{17}$.

1) Pengetahuan biasa adalah pengetahuan tentang hal-hal biasa, kejadian sehari-hari, yang selanjutnya disebut pengetahuan.

2) Pengetahuan ilmiah adalah pengetahuan yang mempunyai sistem dan metode tertentu, yang selanjutnya disebut ilmu pengetahuan.

3) Pengetahuan filosofis adalah semacam ilmu istimewa yang mencoba menjawab istilah-istilah yang tidak terjawab oleh ilmu biasa, yang sering disebut sebagai filsafat.

4) Pengetahuan teologis adalah pengetahuan tentang keagamaan, pengetahuan tentang pemberitahuan dari Tuhan.

a. Sifat Pengetahuan

Dalam suatu kurikulum, uraian ragam pengetahuan tadi dikaitkan dengan sifat pengetahuan. Sifat pengetahuan dianggap sebagai penjelasan atau uraian tentang jenjang, kedalaman kemampuan atau kompetensi yang harus dikuasai oleh seseorang peserta dalam belajarnya, berikut urutan penyampaian pengetahuan. Sifat pengetahuan mempengaruhi pertimbangan penyusun kurikulum. Sesungguhnya peran sifat pengetahuan terkait dengan analisis

${ }^{17}$ Muhammad Nurdin, Kiat Menjadi Guru Profesional, (Yogyakarta: Prismasophie, Cet. ke-I, 2004), hlm. 139. 
tugas belajar atau Learning task analysis. Bidang arsitektur terdiri atas beberapa sifat pengetahuan yang dituangkan dalam satuan mata kuliah. Setiap sifat pengetahuan mengandung seluruh atau sebagian ragam pengetahuan. ${ }^{18}$

\subsection{Kemudahan}

Kemudahan berarti keyakinan individu bahwa menggunakan sistem teknologi informasi tidak akan merepotkan atau membutuhkan usaha yang besar pada saat digunakan. ${ }^{19}$ Persepsi kemudahan penggunaan didefinisikan sebagai penilaian seseorang mengenai suatu teknologi bahwa tidak perlukemampuan yang tinggi untuk menggunakannya. ${ }^{20}$ Dari definisinya maka dapat diketahui bahwa persepsi kemudahan merupakan suatu kepercayaan tentang proses pengambilan keputusan. Jika seseorang percaya bahwa sistem informasi mudah digunakan maka dia akan menggunakannya. Sebaliknya jika seseorang merasa yakin bahwa system informasi tidak mudah digunakan maka dia tidak akan menggunakannya.

${ }^{18}$ Nurdin, N., Pettalongi, S. S., \& Yusuf, K. (2018). Knowledge Management Model in Syariah Banking. 2018 5th International Conference on Information Technology, Computer, and Electrical Engineering (ICITACEE)

19 Andriyanto, Yaufi. "Pengaruh Persepsi

Kemudahan, Persepsi Kebermanfaatan, Persepsi Risiko dan Kepercayaan Terhadap Minat Menggunakan Rekening Ponsel (Studi Kasus Pada Nasabah CIMB NIAGA Daerah Istimewa Yogyakarta)".Skripsi.Fakultas Ekonomi Universitas Negeri Yogyakarta.2014. h.43.

20 Nasution, dan Fahmi Natigor, Penggunaan Teknologi Informasi berdasarkan Aspek Prilaku, Universitas Sumatra Utara Digital Library, 2004,h.5.
Dari definisi diatas, diketahui bahwa persepsi kemudahan penggunaan merupakan suatu sikap dimana seseorang berpikir bahwa menggunakan suatu teknologi akan bebas dari usaha. Variabel kemudahan penggunaan Fintech didefinisikan sebagai suatu keyakinan dimana seseorang berpikir bahwa penggunaan layanan Fintech tersebut dapat dengan mudah untuk dipahami, dipelajari dan digunakan. Dalam penelitian ini kemudahan bagi mahasiswa IAIN Palu percaya bahwa bertransaksi menggunakan Fintech akan memberikan waktu yang lebih efisien dan akan berkelanjut dimasa yang akan datang.

Apabila pengguna beranggapan Fintech mudah dipelajari, maka layanan tersebut mudah untuk digunakan dan akan sering digunakan oleh pengguna. Apabila para pengguna beranggapan bahwa Fintech mudah dipahami, simpel dan mudah pengoperasiannya, maka layanan tersebut mudah untuk dijalankan dan tidak membutuhkan banyak usaha. Sebaliknya, jika para nasabah beranggapan Fintech tidak mudah untuk dipelajari, tidak simpel, terlalu rumit dan susah dalam pengoperasiannya, maka layanan Fintech tersebut tidak menimbulkan rasa minat bagi para penggunanya.

Suatu teknologi dikatakan memiliki suatu kemudahan dalam penggunaanya apabila memiliki beberapa indikator sebagai berikut. ${ }^{21}$

1. Mudah dan terampil dalam menggunakan suatu teknologi.

${ }^{21}$ Mustofa abdul karim (2017). "Pengaruh Sistem Pembayaran Go-pay Menggunakan TAM (Technology Acceptence Model) Terhadap Intensitas penggunaan Layanan Gojek". Skripsi FE UII.

e-ISSN: 2686-6633 
2. Teknologi tersebut dapat dengan mudah untuk dipelajari.

3. Sangat mudah dalam pengoperasiannya.

Kemudahan dalam bertransaksi dengan menggunakan Fintech disediakan oleh pihak perusahaan start up agar mudah untuk dipahami dan mudah untuk digunakan. Adanya kemudahan ini menjadikan konsumen tidak memerlukan usaha yang tinggi untuk mempelajarinya. Selain itu kemudahan yang diberikan oleh layanan Fintech dapat dilakukan dimana saja dan kapan saja. Hal ini bisa dikatakan bahwa sistem teknologi Fintech bekerja untuk memudahkan penggunanya daripada seseorang yang tidak menggunakan sistem tersebut.

kemudahan memberikan indikasi bahwa suatu system dirancang bukan unruk menyulitkan pemakainya, akan tetapi pengguna sistem justru mempermudah seseorang dalam menyelesaikan pekerjaannya. Dengan kata lain seseorang yang menggunakan system akan bekerja lebih mudah dibandingkan dengan seseorang yang tidak menggunakan system atau manual. 22

Kemudahan yang dirasakan mempengaruhi sikap individu dalam dua mekanisme yaitu self-efficacy dan Intrumentaly. Semakin mudah teknologi digunakan maka akan meningkatkan self-eficacy penggunanya.Kemudahan yang dirasakan juga memberikan dampak dalam memperbaiki kinerja seseorang. ${ }^{23} \mathrm{Hal}$ ini menunjukan bahwa

\footnotetext{
22 Andriyanto 2014, h.44.

${ }^{23}$ Panggih Dwi Istiarni (2014)." Analisis

Pengaruh Persepsi Manfaat, Kemudahan Penggunaan dan Kredibilitas terhadap Minat Penggunaan Berulang Internet Banking dengan
}

semakin banyak kemudahan yang dapat dirasakan dari penggunaan teknologi atau sistem maka dapat mempengaruhi ketertarikan penggunanya.

\subsection{Risiko}

Risiko merupakan Suatu keadaan uncertainty yang dipertimbangkan orang untuk memutuskan atau tidak melakukan transaksi secara online. ${ }^{24}$

Risiko merupakan ketidakpastian dan konsekuensi-konsekuensi tidak diinginkan dalam melakukan suatu kegiatan tertentu. Risiko yang dipersepsikan didefinisikan sebagai ketidakpastian yang dihadapi konsumen ketika mereka tidak mampu melihat kemungkinan yang akan terjadi dari keputusan pembelian yang dilakukan. Sebelum memilih suatu produk atau layanan, konsumen tentu akan mempertimbangkan risiko dari penggunaan produk atau layanan tersebut. Sama halnya dengan penggunaan Fintech, konsumen tentu akan memutuskan menggunakan layanan berbasis transaksi online atau tidak, mengingat risiko yang mungkin dihadapi begitu tinggi. Risiko penggunaan transaksi online dapat dikatakan tinggi, karena konsumen tidak dapat melakukan transaksi secara tatap muka atau berinteraksi secara langsung antara pengguna dan pengembang.

Sikap Penggunaan Sebagai Variabel Intervening". Skripsi FEBI UNDIP Semarang.

24 Amijaya, Gilang Rizky. "Pengaruh Persepsi Teknologi Informasi, Kemudahan, Risiko Dan Fitur Layanan Terhadap Minat Ulang Nasabah Bank Dalam Menggunakan Internet Banking (Studi Pada Nasabah Bank BCA)". Skripsi. Fakultas Ekonomi Universitas Diponegoro.2010.h.36.

e-ISSN: $2686-6633$ 
Risiko merupakan suatu ketidakpastian yang akan diterima pengguna dalam menggunakan Fintech. Risiko dapat dibagi dalam lima dmensi, diantaranya adalah:

a. Risiko Psikologi (physcological risk), perasaan, emosi ataupun ego yang dirasakan oleh individu karena membeli atau menggunakan suatu produk.

b. Risiko Keuangan (financial risk), individu merasakan masalah keuangan setelah membeli atau menggunakan suatu produk

c. Risiko Kinerja (functional risk), individu tidak mendapatkan fungsi dari suatu produk sesuai yang mereka harapkan

d. Risiko Fisik (pysical risk), dampak negatif dari suatu produk yang dirasakan oleh pengguna setelah menggunakannya

e. Risiko Sosial (social risk), risiko ini dipengaruhi oleh lingkungan sekitar pengguna atas penggunaan suatu produk.

f. Risiko waktu, risiko yang diterima berupa hilangnya waktu konsumen akibat pembelian produk. 25

Semakin tinggi tingkat risiko yang di dapat oleh individu maka semakin rendah tingkat kepercayaan individu. Sebaliknya semakin rendah tingkat risiko yang di dapat oleh individu maka semakin tinggi tingkat kepercayaan individu.

\subsection{Minat}

25 Suryani, Tatik. "Perilaku Konsumen di Era Internet: Implikasi pada Strategi Pemasaran". Yogyakarta : Graha Ilmu. 2013, h. 86-87.
Minat adalah suatu kondisi dimana seseorang memiliki perhatian terhadap sesuatu serta mempunyai keinginan untuk mengetahui dan mempelajari maupun membuktikan lebih lanjut. ${ }^{26}$ Sedangkan menurut Adhitama

" Minat adalah rasa ketertarikan pada suatu hal atau aktivitas tanpa ada paksaan dan merasa senang untuk mempelajarinya." 27

Rasa ketertarikan tersebut bukan karena paksaan tapi kesadaran yang tinggi karena keinginan yang kuat untuk mencapai tujuannya. Pendapat lain mengenai minat adalah suatu rasa lebih suka dan rasa ketertarikan pada suatu hal atau aktivitas tanpa ada paksaan. ${ }^{28}$ Jadi minat adalah dorongan dari psikis individu untuk melakukan sesuatu atau menggunakan tanpa dorongan dari pihak lain. Dalam penelitian ini minat dapat diartikan sebagai ketertarikan individu dalam bertransaksi menggunakan Fintech.

Minat dapat dipengaruhi oleh faktor internal maupun eksternal. Ada tiga faktor yang dapat mempengaruhi minat setiap individu diantaranya adalah:

1. Faktor yang berasal dari dalam diri individu yg berhubungan dengan jasmani dan rohani.

26 Walgito Bimo."Pengantar Psikologi Umum". Yogyakarta : Yayasan Penerbitan Fakultas Psikologi UGM.1981.h.32.

27 Paulus Adhitama, Faktor-Faktor yang Mempengaruhi Minat Berwiarausaha, Jurnal Fakultas EkonomiUniversitas Diponegoro, 2014, h.13.

$\begin{array}{ccr}28 & \text { Sumadi } & \text { Surabirta.Psikologi } \\ \text { Pendidikan". } & \text { PT.Grafindo } & \text { Perkasa } \\ \text { rajawali:Jakarta.2002.h.68. } & & \end{array}$

e-ISSN: 2686-6633 
2. Faktor Motif Sosial, yaitu kebutuhan untuk mendapatkan penghargaan dan lingkungan individu berada.

3. Faktor Emosional, yaitu ukuran intensitas seseorang dalam menaruh perhatian terhadap keinginan atau objek tertentu. ${ }^{29}$

Minat setiap individu tergantung dari faktor-faktor yang mempengaruhinya, setiap individu memiliki minatnya masing-masing. Meskipun individu memiliki minat yang sama terhadap sesuatu namun dilatarbelakangi oleh faktor tertentu. Untuk mengukur minat ada beberapa indikator yang dapat digunakan diantarnaya adalah: 30

1. Rasa ingin Menggunakan.

2. Selalu menggunakan.

3. Berlanjut menggunakan di masa yang akan datang. ${ }^{31}$

\section{$3 \quad$ Financial Technology (Fintech)}

a. Pengertian Fintech

Isilah Fintech berasal dari Financial Technology atau teknology finansial. Financial Technlogy atau Fintech adalah penggunaan teknologi untuk memberikan solusi keuangan. ${ }^{32}$ Pengertian lain mengenai Fintech adalah sebuah istilah yang digunakan guna

29 Yusuf Fitra Mulyana."Pengaruh Kepercayaan, Persepsi Risiko dan Keamanan Terhadap Minat Beli Konsumen Pada Toko Online". Skripsi, FE UNDIP, Semarang.2016.

30 Paul A. Pavlou. "Consumer Acceptance of Electronic Commerce: Integrating, Trust and Risk with the Technology Acceptance Model". International journal of Electronic Commerce,2010. Vol.7.

31 Jogiyanto,Sistem Informasi Keperilakuan. Yogyakarta:Andi.2007. Hlm. 33

32 Douglas Amer, Et.al, "The Evolution of Fintech : A new Post-crisis Paradigm?", Research Paper No.2015/047, University of Hong Kong Faculty of Law, 2015. menunjukan perusahaan yang menawarkan teknologi modern pada sektor keuangan. ${ }^{33}$

Teknogi Finansial menurut peraturan Bank Indonesia Nomor 19/12/PBI/2017 adalah penggunaan teknologi sistem keuangan yang menghasilkan produk, layanan, teknologi, dan/atau model bisnis baru serta dapat berdampak pada stabilitas moneter, stabilitas sistem keuangan efisiensi, kelancaran, keamanan dan keandalan sistem pembayaran. ${ }^{34}$

Menurut surat edaran Bank Indonesia No.18/22/DKSP tentang Penyelenggara Layanan Keuangan Digital (LKD) menjelaskan bahwa kegiatan layanan keuangan digital adalah penggunaan teknologi berbasis mobile ataupun berbasis web dalam kegiatan layanan sistem pembayaran dan keuangan yang dilakukan dengan kerja sama dengan pihak ketiga dalam rangka keuangan inklusif. 35 Keuangan inklusif merupakan upaya pemerintah mewujudkan kemandirian ekonomi dengan menggerakkan sektor strategis ekonomi domestik. Perpres No.82 Tahun 2016 tentang Strategi Nasional Keuangan Inklusif menetapkan target

33 Svetlana saksonova dan Irina Kusmina Marlino. "Fintech as Financial Inovation-the possibilities and problems of Implementation". European studies research journal, vol.XX, issue 3A,pp.961-973.2017.

34 Peraturan Bank Indonesia, Situs Bank Indonesia. Website: https:// www.bi.go.id (diakses 22 Juni 2020)

35 Bank Indonesia, Surat edaran No.18/22/DKSP "Penyelenggara Layanan Keuangan Digital" 2016

e-ISSN: $2686-6633$ 
$75 \%$ populasi dewasa dapat mengakses layanan keuangan formal pada 2019.36

Transaksi keuangan melalui Fintech ini meliputi pembayaran, investasi, peminjaman uang, transfer, rencana keuangan dan pembanding produk keuangan. Sampai 30 September 2019 total jumlah penyelenggaraan Fintech terdaftar dan berizin adalah sebanyak 127 perusahaan. ${ }^{37}$

b. Jenis-Jenis Fintech

Perkembangan Fintech di Indonesia sangatlah pesat. Telah banyak berdiri perusahaan yang mengembangkan layanan keuangan berbasis teknologi. Ada beberapa Fintech yang ada di Indonesia diantaranya adalah Payment Settlement and Clearing, Crowdfunding and P2P, Market Agregator, Risk and Investment Management. ${ }^{38}$

\section{1) Payment Settlement and Clearing}

Payment system adalah layanan elektronik yang menggantikan uang kartal dan uang giral sebagai alat pembayaran seperti e-walet, kartu emoney, bitcoin, dan bentuk aplikasi Fintech lain. ${ }^{39}$ Di indonesia produk Fintech yang banyak digunakan adalah produk payment yaitu sebesar $38 \%$. Berbagai jenis produk payment telah meramaikan industri Fintech seperti: emoney card, kartu e-toll, e-wallet, dan bentuk aplikasi lain dengan berbagai

\footnotetext{
${ }^{36}$ Strategi Nasional Keuangan Inklusif, Situs

Badan Perencanaan Pembangunan Nasional.

Website:bappenas.go.id.

${ }^{37}$ Financial Technology, Situs Otoritas Jasa Keuangan. Website: https://www.ojk.go.id.

38 Jenis-jenis Fintech, Situs Bank Indonesia. Website:https:www.bi.go.id (diakses 22 Juni 2020)

${ }^{39}$ Alvani Amaerita Harefa dan Posma Sariguna Johnson Kennedy, Financial Technology, Regulasi dan Adaptasi Perbankan di Indonesia.Vol 3, No.1

(2018).ejournal.uki.ac.id (diakses 26 November 2019)
}

merk seperti: Go Pay, OVO, T-cash, XL pay, Line pay, True Money, M-sau, Paytren, Dana, Uangku, Saldomu dan merekmerek yang lain.

2) Crowdfunding dan Peer to Peer Lending (P2P Lending)

Crowdfunding adalah suatu bentuk penggalangan dana untuk berbagai jenis usaha baik ide produk, bisnis, atau kegiatan yang dananya dari sumbangan masyarakat luas dan sering memiliki suatu imbalan berupa barang dan jasa. Crowdfunding merupakan bentuk kerjasama kolektif perhatian dan kepercayaan masyarakat luas yang saling terhubung dan menggalang dana untuk mendukung suatu proyek tertentu yang dipelopori oleh individu maupun kelompok. Dalam crowdfunding investor berkontribsi secara finasial untuk membiayai sebuah proyek. Dapat disimpulkan bahwa crowdfunding merupakan suatu jenis kegiatan penggalangan dana yang memanfaatkan social media, web, dan aplikasi serta sarana teknologi informasi lainnya untuk mendukung suatu proyek tertentu dengan melibatkan masyarakat luas dengan imbalan barang dan jasa.

3) Mark Aggregrator

Menurut Clare dan Rebecca dalam Muhammad Wildan Market Aggragator atau e-aggregator adalah layanan yang mengumpulkan dan menganalisa informasi keuangan dengan transparan dari berbagai sumber. Dalam layanan ini pihak aggregator menafsirkan informasi dengan berbagai cara dari semua berdasarkan makna dan konteks dari informasi yang telah dikumpulkan. Eaggregator dapat dijadikan sebuah platform yang menggabungkan berbagai informasi mengenai perusahaan untuk investor seperti risiko, imbal hasil dan e-ISSN: $2686-6633$ 
dampak dan kelayakan kredit dari populasi target. ${ }^{40}$

Di Indonesia sudah ada beberapa layanan penyedia informasi berbasis elektronik yang memberikan perbandingan produk mulai dari harga fitur dan manfaat seperti: Cekaja, Cermati, KreditGogo dan Tunaiku.

4) Risk and Investment Management

Dalam industri Fintech risk and investment management dikenal dengan istilah Robo-Advisor yaitu layanan yang memberi saran atau menglola kekayaan prbadi dan menggantikan pengelolaan kekayaan tradisional. Robo-Advisor merupakan solusi investasi otomatis berbasis teknologi digital yang melibatkan individu untuk dilakukan pembinaan dalam pengambilan keputusan yang didukung dengan penyeimbangan portofolio menggunakan algoritma perdagangan berdasarkan investasi pasif dan strategi diversifikasi. Pada intinya risk and investment management merupakan sebuah layanan pengelolaan kekayaan pribadi dengan alat teknologi digital yang memberikan saran dala pengambilan keputusan individu. ${ }^{41}$

Di Indonesia pengunaan layanan Robo-Advisor sudah banyak berkembang dengan adanya berbagai perusahaan pengembang di bidang ini seperti : Bareksa, Cek Premi, Raja Premi. Gambar 1. Kerangka Pikir

\footnotetext{
${ }^{40}$ Muhammad Wildan. "Pengaruh Persepsi Kemudahan...

$$
41 \text { Ibid. }
$$
}

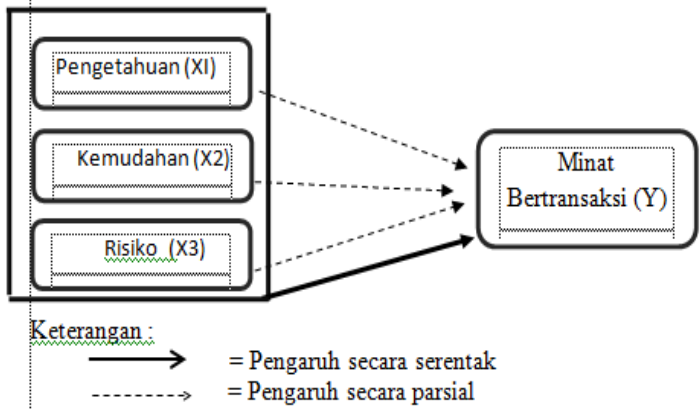

\section{Metode Penelitian}

Pendekatan yang digunakan dalam penelitian ini adalah pendekatan kuantitaif, karena penelitian ini terfokus untuk mengetahui pengaruh variabel pengetahuan, kemudahan, dan resiko terhadap minta bertransaksi dengan Fintech.

Penelitian ini dilakukan di Institut Agama Islam Negeri (IAIN) Palu yang bertempat di Jl. Diponegoro No.23, Kecamatan Palu Barat, Kota Palu, Sulawesi Tengah. Lokasi ini di ambil oleh peneliti dengan pertimbangan bahwa lokasi tersebut mudah untuk diakses dan dijangkau dan juga mahasiswa merupakan objek dalam penelitian ini. Peneliti memberikan questioner kepada 98 respondent mahasiswa di empat fakultas yang ada di IAIN Palu. Quesioner menggunakan lima skala likert.

Teknik analisis data yang digunakan dalam penelitian ini adalah analisis kuantitaif, yaitu proses analisis terhadap data-data yang berbentuk angka dengan cara perhitungan secara statistik untuk mengukur pengaruh ketiga variabel tersebut terhadap minat menggunakan Fintech. an pembelian. ${ }^{42}$

42 Nurdin, N., Musyawarah, I., Nurfitriani, N., \& Jalil, A. (2020). Pengaruh Pelayanan Mobile Banking Terhadap Kepuasan e-ISSN: 2686-6633 
Analisa data dilakukan melalui tahap uni validitas, reabilitas, uji regresi berganda, dan uji asumsi klasik. Untuk oembuktian hipotesis penulis menggunakan uji f dan uji t.

\section{Hasil dan Pembahasan}

\subsection{Deskripsi Sample}

Jumlah sampel yang digunakan dalam penelitian ini adalah 98 orang mahasiswa IAIN Palu. Adapun distrubusi sampel penelitian dapat dilihat pada tabel 1 berikut ini.

Tabel 1. Distribusi Respondent

\begin{tabular}{|c|c|c|c|}
\hline \multirow{2}{*}{ Fakultas } & \multicolumn{2}{|c|}{ Jumlah } & \multirow{2}{*}{ Persentase } \\
\cline { 2 - 3 } & L & P & \\
\hline FTIK & 20 & 31 & $52 \%$ \\
\hline FUAD & 7 & 8 & $15,3 \%$ \\
\hline FASYA & 4 & 4 & $8,2 \%$ \\
\hline FEBI & 11 & 13 & $24,5 \%$ \\
\hline Jumlah & 42 & 56 & $100 \%$ \\
\hline
\end{tabular}

Pada tabel 1 menunjukkan bahwa jumlah responden dari setiap fakultas dimana responden berasal dari Fakultas Tarbiyah dan Ilmu Keguruan (FTIK) yaitu sebanyak 51 (52\%) kemudian dari Fakultas Ushuluddin Adab dan Dakwah (FUAD) yaitu sebanyak 15 responden (15,3\%), kemudian dari Fakultas Syariah (FASYA) yaitu sebanyak 8 responden $(8,2 \%)$, dan yang

Nasabah (Studi Pada Mahasiswa Perbankan Syariah IAIN Palu) Jurnal Ilmu Perbankan dan Keuangan Syariah, 2(2), 87-104. terakhir dari fakultas Fakultas Ekonomi dan Bisnis Islam (FEBI) yaitu sebanyak 24 responden $(24,5 \%)$.

1. Uji Validitas

Validitas adalah tingkat keandalan dan kesahihan alat ukur yang digunakan. Intrumen dikatakan valid berarti menunjukkan alat ukur yang dipergunakan untuk mendapatkan data itu valid atau dapat digunakan untuk mengukur apa yang seharusnya di ukur (Sugiyono, 2004:137). ${ }^{43}$

Menurut Sugioyono dalam Sakinah, apabila validitas setiap jawaban yang diperoleh ketika memberikan daftar pertanyaan lebih besar dari 0,3 maka pertanyaan dianggap sudah valid. ${ }^{4}$

Instrument yang dinyatakan valid dan reliabel adalah instrument yang valid, berarti alat ukur yang digunakan untuk mendapatkan data (mengukur) itu valid. Sedangkan instrumen yang reliabel berarti bila digunakan untuk mengukur berkalikali akan menghasilkan data yang sama.

Uji Validitas data penelitian ditentukan oleh proses pengukuran yang akurat. Suatu instrumen pengukur dikatakan valid instrumen tersebut mengukur apa yang seharusnya di ukur. Instrumen tersebut dapat mengukur konstrak sesusai yang yang diharapkan peneliti. Pendekatan yang dilakukan dalam penelitian ini adalah validitas konstrak (susunan), yang ditetapkan menurut analisis rasional

${ }^{43}$ Agus Tri Basuki, Penggunaan SPSS Dalam Statistik, (Edisi Revisi, Yogyakarta: Danisa Media, 2015), 65.

44 Sakinah, Pengaruh Bauran Pemasaran Keputusan Membeli Kartu Prabayar Produk Telkomsel Pada Mahasiswa IAIN Palu, Skripsi (Palu: IAIN 2014), 5.

e-ISSN: 2686-6633 
terhadap isi test atau angket yang penilaiannya didasarkan pada pertimbangan subjektif individual dengan mempertimbangkan baik teori maupun instrumen pengukur itu sendiri. Menghitung korelasi antara masing-masing pertanyaan dengan skor total korelasi. Semua item pertanyaan yang mencapai batas minimal koefisien korelasi 0,30 dianggap memuaskan. ${ }^{45}$

Tabel 2 dibawah ini, memberlihatkan bahwa nilai $r_{\text {hitung }}$ pada kolom Corrected Item Total Correlation untuk masing-masing dari ke 4 variabel di atas dinyatakan semua pernyataan valid karena $r_{\text {hitung }}$ lebih besar dan positif dari 0,30 .

${ }^{45}$ Rasdihan Rasyad, Metode Statistik

Deskriptif (Jakarta: Grasindo, 2000), 247.

e-ISSN: 2686-6633 
Tabel 2

Hasil Uji Validitas Instrumen

\begin{tabular}{|c|c|c|c|c|}
\hline \multirow{2}{*}{ Variabel } & Item Pernyataan & $\begin{array}{c}\text { Corrected } \\
\text { Item total } \\
\text { Correlation }\end{array}$ & $\begin{array}{c}\mathrm{R} \\
\text { Kritis }\end{array}$ & Ket. \\
\hline \multirow{3}{*}{ Pengetahuan (X1) } & 1 & 0,504 & 0,30 & Valid \\
& 2 & 0,575 & 0,30 & Valid \\
& 3 & 0,521 & 0,30 & Valid \\
\hline \multirow{3}{*}{ Kemudahan (X2) } & 1 & 0,649 & 0,30 & Valid \\
& 2 & 0,693 & 0,30 & Valid \\
& 3 & 0,509 & 0,30 & Valid \\
& 4 & 0,518 & 0,30 & Valid \\
\hline Risiko (X3) & 2 & 0,652 & 0,30 & Valid \\
& 3 & 0,708 & 0,30 & Valid \\
& 4 & 0,472 & 0,30 & Valid \\
& 1 & 0,555 & 0,30 & Valid \\
\hline \multirow{2}{*}{ Minat Bertransaksi } & 2 & 0,415 & 0,30 & Valid \\
& 3 & 0,679 & 0,30 & Valid \\
& 4 & 0,673 & 0,30 & Valid \\
& & 0,713 & 0,30 & Valid \\
\hline
\end{tabular}

Sumber Data: Output SPSS 2020

Uji reliabilitas berguna untuk menetapkan apakah instrumen yang dalam hal ini kuesioner dapat digunakan lebih dari satu kali, paling tidak oleh responden yang sama akan menghasilkan data yang konsisten. Dengan kata lain, reliabilitas instrumen mencirikan tingkat konsistensi. Pengukuran realibitas menggunakan cara one shot atau pengukuran sekali saja yaitu: Pengukuran hanya sekali saja dan kemudian hasilnya dibandingkan dengan pertanyaan lain atau mengukur korelasi antar jawaban pertanyaan. SPSS memberikan fasilitas untuk mengukur relibilitas dengan uji statistik cronbach alpha (a) suatu variabel dikatakan realibel jika memberikan nilai cronbach alpha> 0,60.

Hasil pengujian reliabilitas instrument menggunakan alat bantu oleh statistik SPSS versi 21 for windows dapat diketahui sebagaimana tabel berikut.

Tabel 3

Hasil Uji Reabilitas Instrumen

\begin{tabular}{|c|c|c|c|}
\hline Variabel & $\begin{array}{c}\text { Reliability } \\
\text { Coefficiens }\end{array}$ & $\begin{array}{c}\text { Cronbach } \\
\text { Alpha }\end{array}$ & Keterangan \\
\hline Pengetahuan (X1) & 3 Item & 0,706 & Reliabel \\
\hline Kemudahan (X2) & 4 Item & 0,779 & Reliabel \\
\hline
\end{tabular}

e-ISSN: 2686-6633 


\begin{tabular}{|c|c|c|c|}
\hline Risiko (X3) & 4 Item & 0,786 & Reliabel \\
\hline Minat Bertransaksi (Y) & 4 Item & 0,795 & Reliabel \\
\hline
\end{tabular}

Sumber Data: Output SPSS 2020

Dari tabel di atas dapat diketahui bahwa masing-masing variabel memiliki Cronbach's Alpha (a) lebih dari 0,60 (a > $0,60)$, yang artinya bahwa semua variabel yaitu X1, X2, X3, dan Y adalah reliabel. Dengan demikian pengolahan data dapat dilanjutkan ke jenjang selanjutnya.

\subsection{Uji Heteroskedastisitas}

Model regresi terbaik adalah yang tidak terjadi heteroskedastisitas. Untuk menguji asumsi ini dilakukan dengan melalui garfik scatterplot antara variabel terikat (ZPRED) dan variabel bebas (SRESID).

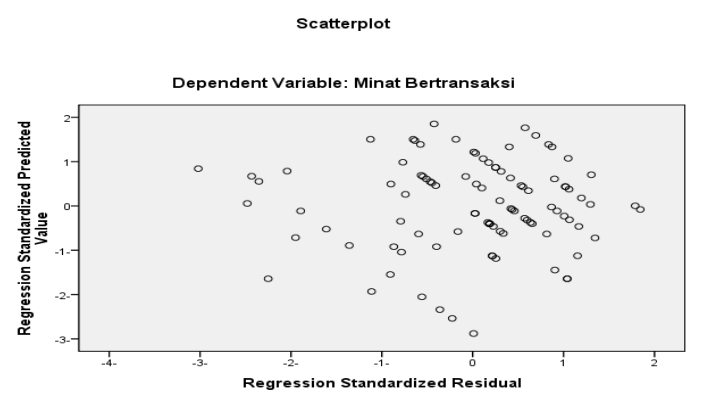

Berdasarkan gambar grafik di atas terlihat bahwa titik-titik atau poin-poin menyebar di atas dan di bawah angka 0 dan sumbu Y. maka dapat disimpulkan bahwa tidak terjadi heteroskedastisitas pada model regresi.

\subsection{Uji Multikolinearitas}

Pada tabel berikut ini dapat dilihat hasil uji multikolinearitas yang menunjukkan nilai VIF dan tolerance untuk masing-masing variabel independen.

Tabel 4. Hasil Uji Multikolinearitas

Hasil Uji Multikolinearitas

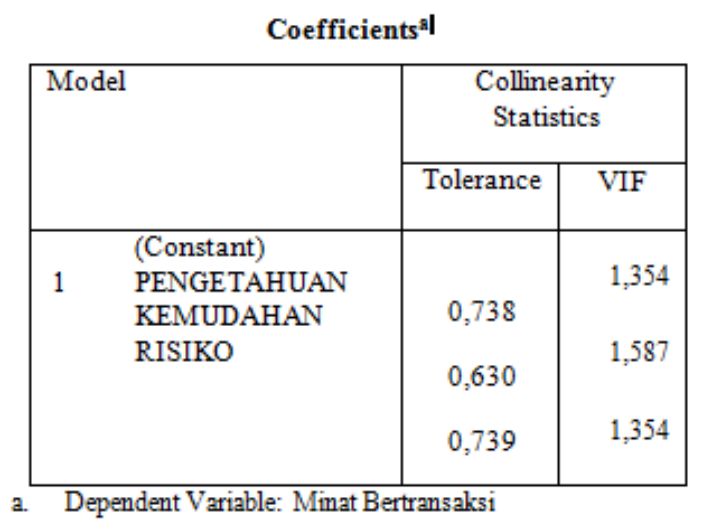

Berdasarkan tabel tersebut, menunjukkan bahwa dalam model regresi bebas dari adanya multikolinear. Hal ini dapat dilihat dari perhitungan nilai Tolerance menunjukkan tidak ada variabel independen yang memiliki nilai Tolerance yang kurang dari 0,10. Selain itu, hasil perhitungan nilai Variance Inflation Factor (VIF) juga menunjukkan hal yang sama yaitu tidak ada satupun variabel independen yang menunjukkan nilai VIF lebih dari 10. Jadi dapat disimpulkan bahwa tidak ada multikolinearitas antara variabel independen dalam model regresi.

\subsection{Analisis Regresi Linear Berganda}

Analisis regresi linear berganda adalah salah satu alat statistik nonparametrik yang berfungsi menganalisis keterkaitan dan e-ISSN: 2686-6633 
keterhubungan di antara dua atau lebih variabel penelitian yang berbeda, yaitu variabel dependen dan independen dengan membutuhkan data terdiri dari beberapa kelompok hasil observasi pengukuran. Selanjutnya dari hasil analisis regresi berganda ini akan diketahui ada tidaknya pengaruh secara parsial dan simultan variabel Pengetahuan (X1), Kemudahan (X2) dan Risiko (X3) terhadap Minat Bertransaksi (Y).

Berdasarkan hasil olah data menggunakan SPSS 21 for Windows diperoleh hasil analisis regresi berganda sebagai berikut:

Tabel 5

Hasil Analisis Regresi Linear Berganda

Coefficients $^{\mathrm{a}}$

\begin{tabular}{|c|c|c|c|c|c|c|c|c|}
\hline \multirow{2}{*}{\multicolumn{2}{|c|}{ Model }} & \multicolumn{2}{|c|}{$\begin{array}{l}\text { Unstandardized } \\
\text { Coefficients }\end{array}$} & \multirow{2}{*}{\begin{tabular}{|c|}
$\begin{array}{c}\text { Standardized } \\
\text { Coefficients }\end{array}$ \\
Beta \\
\end{tabular}} & \multirow[b]{2}{*}{$\mathrm{t}$} & \multirow[b]{2}{*}{ Sig. } & \multicolumn{2}{|c|}{ Collinearity Statistics } \\
\hline & & B & Std. Error & & & & Tolerance & VIF \\
\hline \multirow[t]{4}{*}{1} & (Constant) & 2.416 & 2.245 & & 1.076 & .285 & & \\
\hline & pengetahuan & .130 & .133 & .230 & 979 & .330 & .630 & 1.587 \\
\hline & Kemudahan & .420 & .180 & .104 & .2337 & .022 & .738 & 1.354 \\
\hline & Risiko & .380 & .099 & .376 & 3.828 & .000 & .739 & 1.354 \\
\hline
\end{tabular}

a. Dependent Variable: Minat

Bertransaksi

Hasil analisis regresi linear berganda pada tabel di atas, kemudian dimasukkan ke dalam model persamaan regresi berganda sebagai berikut:

$$
\mathrm{Y}=2,416+0,420 \mathrm{x}_{1}+0,130 \mathrm{x}_{2}+
$$

$0,380 \times 3+e$

Persamaan regresi linear berganda di atas menunjukkan bahwa ketiga variabel independen (pengetahuan, kemudahan dan risiko) memiliki arah yang positif terhadap variabel dependen (minat bertransaksi). Hasil perhitungan di atas dapat dijelaskan sebagai berikut:

a) Nilai konstanta sebesar 2,416 berarti bahwa jika variabel pengetahuan, kemudahan, dan risiko memiliki nilai nol maka minat bertransaksi menggunakan Fintech sebesar 2,416.

b) Nilai 0,130 pada variabel pengetahuan $\left(\mathrm{X}_{1}\right)$ adalah bernilai positif sehingga dapat dikatakan bahwa adanya pengetahuan tentang Fintech akan meningkatkan minat bertransaksi menggunakan Fintech mahasiswa IAIN Palu sebesar 13\%. Dengan asumsi variabel bebas yang lain dianggap konstan.

c) Nilai 0,420 pada variabel kemudahan $\left(\mathrm{X}_{2}\right)$ adalah bernilai positif sehingga dapat dikatakan bahwa jika kemudahan semakin mudah digunakan, semakin mudah dipelajari, semakin mudah dipahami dan semakin mudah dioperasikan maka minat mahasiswa dalam bertransaksi menggunakan Fintech akan meningkat sebesar $42 \%$. Dengan asumsi bahwa variabel bebas yang lain dari model regresi adalah konstan.

Nilai 0,380 pada variabel bebas mengartikan bahwa variabel risiko $\left(X_{3}\right)$ 
adalah bernilai negatif memiliki hubungan berlawanan dengan minat bertransaksi menggunakan Fintech. Hal ini menunjukan bahwa semakin tinggi risiko yang ditimbulkan, semakin banyak kerugian yang dirasakan mahasiswa dan semakin membuat mahasiswa beranggapan penggunaan Fintech berisiko maka minat bertransaksi menggunakan Fintech akan menurun sebesar $38 \% \%$. Dengan asumsi bahwa variabel bebas yang lain dalam model regresi adalah konstan.

\subsection{Hasil pengujian Hipotesis}

a). Uji Parsial ( Uji T )

Merupakan teknik analisis untuk membandingkan satu variabel bebas. Teknik ini digunakan untuk menguji apakah nilai tertentu berbeda secara signifikan atau tidak dengan rata-rata sebuah sampel.46 Dikatakan signifikan jika nilai sigifikansi nya kurang dari 0,05 .

a. Variabel Pengetahuan

Variabel Pengetahuan dengan tingkat signifikan 95\% $(\alpha=0,05)$. Angka signifikan ( $\mathrm{P}$ value) pada variabel Pengetahuan sebesar 0,3>0,05. Atas dasar perbandingan tersebut, maka berarti variabel Pengetahuan tidak memiliki pengaruh yang signifikan terhadap minat bertransaksi mahasiswa. Adapun pengaruhnya dapat dilihat pada kolom Beta. Besaran pengaruh variabel $\mathrm{X} 1$ terhadap variabel $\mathrm{Y}$ yaitu $13 \%$.

b. Variabel Kemudahan

Variabel Kemudahan dengan tingkat signifikan 95\% ( $\alpha=0,05)$. Angka signifikan ( $\mathrm{P}$ value) pada variabel Kemudahan sebesar 0,02<0,05. Atas dasar perbandingan tersebut, maka berarti variabel Kemudahan memiliki pengaruh yang signifikan terhadap minat bertransaksi mahasiswa. Adapun pengaruhnya dapat dilihat pada kolom Beta. Besaran pengaruh variabel $\mathrm{X} 2$ terhadap variabel $Y$ yaitu $42 \%$.

c. Variabel Risiko

Variabel Risiko dengan tingkat signifikan $95 \% \quad(a=0,05)$. Angka signifikan ( $\mathrm{P}$ value) pada variabel Risiko sebesar $0,00<0,05$. Atas dasar perbandingan tersebut, maka berarti variabel pengetahuan memiliki pengaruh yang signifikan terhadap minat bertransaksi mahasiswa. Adapun pengaruhnya dapat dilihat pada kolom Beta. Besaran pengaruh variabel X3 terhadap variabel $Y$ yaitu $38 \%$. Variabel risiko memiliki hubungan berlawanan dengan variabel minat bertransaksi menggunakan Fintech. Dengan demikian dapat disimpulkan bahwa variabel risiko berpengaruh negatif dan signifikan terhadap minat bertransaksi menggunakan Fintech.

${ }^{46}$ Ibid., 24. 


\begin{tabular}{|c|c|c|c|c|c|c|c|c|}
\hline \multicolumn{9}{|c|}{$\begin{array}{l}\text { Hasil Uji T (Parsial) } \\
\text { Coefficients }^{\mathrm{a}}\end{array}$} \\
\hline \multirow{2}{*}{\multicolumn{2}{|c|}{ Model }} & \multicolumn{2}{|c|}{$\begin{array}{l}\text { Unstandardized } \\
\text { Coefficients }\end{array}$} & $\begin{array}{c}\text { Standardized } \\
\text { Coefficients }\end{array}$ & \multirow[b]{2}{*}{$\mathrm{t}$} & \multirow[b]{2}{*}{ Sig. } & \multicolumn{2}{|c|}{ Collinearity Statistics } \\
\hline & & B & Std. Error & Beta & & & Tolerance & VIF \\
\hline \multirow[t]{4}{*}{1} & (Constant) & 2.416 & 2.245 & & 1.076 & .285 & & \\
\hline & pengetahuan & .130 & .133 & .230 & 979 & .330 & .630 & 1.587 \\
\hline & Kemudahan & .420 & .180 & .104 & .2337 & .022 & .738 & 1.354 \\
\hline & Risiko & .380 & .099 & .376 & 3.828 & .000 & .739 & 1.354 \\
\hline
\end{tabular}

a. Dependent Variable: Minat

Bertransaksi

\subsection{Pembahasan}

1 Pengaruh pengetahuan terhadap minat bertransaksi menggunakan Fintech

Pengetahuan merupakan faktor dasar dalam membentuk perilaku konsumen Pengetahuan adalah apa yang diketahui atau hasil pekerjaan tahu. Pekerjaan tahu tersebut adalah hasil dari kenal, sadar, insaf, mengerti, dan pandai. ${ }^{47}$ Untuk meningkatkan minat mahasiswa maupun masyarakat terhadap Financial Technology yang sampai saat ini masih rendah maka akan sangat diperlukan informasi ataupun upayah untuk meningkatkan kesadaran dalam hal pengetahuan.

Berdasarkan Uji statistik Variabel Pengetahuan dengan tingkat signifikan $95 \%(a=0,05)$. Angka signifikan ( $\mathrm{P}$ value) pada variabel Pengetahuan tentang Fintech sebesar 0,3>0,05. Atas dasar perbandingan tersebut, maka berarti variabel tidak Pengetahuan memiliki pengaruh yang signifikan terhadap minat bertransaksi mahasiswa. Adapun pengaruhnya dapat dilihat pada kolom Beta. Besaran pengaruh

${ }^{47}$ Amsal Bakhtiar, Filsafat Imu. ( Jakarta: PT RajaGrafindo Persada, 2012), 85. variabel $\mathrm{X} 1$ terhadap variabel $\mathrm{Y}$ yaitu $13 \%$

Hasil penelitian ini mendukung penelitian sebelumnya yang dilakukan oleh Arnando Arnold, yang menyatakan bahwa variabel pengetahuan tidak memberikan pengaruh yang signifikan serta tidak berpengaruh positif terhadap minat nasabah menggunakan jasa gadai online. ${ }^{48}$.

2. Pengaruh Kemudahan terhadap minat bertransaksi menggunakan Fintech.

Kemudahan didefinisikan sebagai penilaian seseorang mengenai suatu teknology bahwa tidak perlu kemampuan yang tinggi untuk menggunakannya. ${ }^{49}$ Dari definisinya maka dapat diketahui bahwa kemudahan merupakan kepercayaan tentang proses pengambilan keputusan. Jika seseorang percaya bahwa sistem informasi mudah digunakan maka dia akan menggunakanya. Sebaliknya, jika seorang merasa bahwa sisttem informasi tersebut tiak mudah digunakan maka ia tidak akan menggunakannya

Berdasarkan uji statistik variabel Kemudahan dengan tingkat signifikan

\footnotetext{
${ }^{48}$ Arnold,Pengaruh Pengetahuan. 2018.

${ }^{49}$ Nasution, penggunaan Teknology Informasi.2004.
}

e-ISSN: 2686-6633 
95\% $(a=0,05) . \quad$ Angka signifikan $(P$ value) pada variabel Kemudahan sebesar 0,02<0,05. Atas dasar perbandingan tersebut, maka berarti variabel Kemudahan memiliki pengaruh yang signifikan terhadap minat bertransaksi mahasiswa. Semakin tinggi kemudahan untuk digunakan dan mudah untuk dipahami maka semakin tinggi minat untuk bertransaksi menggunakan Fintech. Hal ini sesuai kategorisasi persepsi responden yang mana Fintech memiliki kemudahan penggunaan yang tinggi, berarti semakin mudah untuk digunakan maka akan meningkatkan minat pengguna Fintech untuk menggunakan layanan Fintech karena pengguna menganggap kemudahan yang ditawarkan layanan uang elektronik untuk digunakan adalah tinggi. Adapun pengaruhnya dapat dilihat pada kolom Beta. Besaran pengaruh variabel $\mathrm{X} 2$ terhadap variabel Y yaitu $42 \%$.

Hasil penelitian ini mendukung penelitian sebelumnya yang dilakukan oleh Azizi Muamar, yang menyatakan bahwa persepsi kemudahan penggunaan berpengaruh positif dan signifikan terhadap keputusan nasabah menggunakan e-banking pada PT Bank BNI Syariah KC Yogyakarta. ${ }^{50}$

\section{Pengaruh Risiko terhadap minat bertransaksi menggunakan Fintech}

Risiko didefinisikan sebagai perkiraan subjektif individu untuk mendapatkan konsekuensi kerugian dalam menerima suatu hasil yang diinginkan. Menurut Hartono dalam Ida ayu Risiko juga dapat didefinisikan

\footnotetext{
${ }^{50}$ Azizi Muamar, Pengaruh Persepsi Kemudahan, 2016.
}

suatu persepsi pelanggan tentang ketidakpastian dan konsekuensikonsekuensi tidak diinginkan ddalam melakukan suatu kegiatan. ${ }^{51}$

Berdasarkan uji statistik variabel Risiko dengan tingkat signifikan 95\% (a $=0,05$ ). Angka signifikan (P value) pada variabel Risiko sebesar $0,00<0,05$. Atas dasar perbandingan tersebut, maka berarti variabel Pengetahuan memiliki pengaruh yang signifikan terhadap minat bertransaksi mahasiswa. Adapun pengaruhnya dapat dilihat pada kolom Beta. Besaran pengaruh variabel X3 terhadap variabel $Y$ yaitu 38\%. Pada penelitian ini diketahui bahwa persepsi risiko memiliki sifat negatif, sehingga dapat disimpulkan bahwa persepsi risiko berpengaruh negatif dan signifikan terhadap minat bertransaksi menggunakan Fintech. Dengan demikian dapat disimpulkan bahwa variabel risiko berpengaruh negatif dan signifikan terhdap minat bertransaksi menggunakan Fintech.

Hal ini menunjukkan semakin tinggi ketidakpastian dan konsekuensi yang diterima oleh seseorang maka semakin rendah minat untuk bertransaksi menggunakan Fintech atau bahkan akan cenderung untuk menghindarinya. Namun, bila semakin rendah timbulnya ketidakpastian dan konsekuensi risiko yang diterima oleh seseorang maka semakin tinggi minat untuk menggunakan layanan uang elektronik.

Hasil penelitian ini mendukung penelitian sebelumnya yang dilakukan

51 Ida Ayu Agung UJ," Peran Kepercayaan Memediasi Persepsi Risiko Terhadap Niat Menggunakan Mandiri Mobile Banking di Kota Denpasar".E-Jurnal Manajemen Unud, Vol.7,No.5,2018.h.2621

e-ISSN: $2686-6633$ 
oleh Muhammad Wildan, yang menyatakan bahwa variabel risiko berpengaruh negatif dan signifikan terhadap minat bertransaksi menggunakan Fintech pada mahasiswa Febi Uin Walisongo Semarang. ${ }^{52}$

\section{Kesimpulan}

Berdasarkan hasil penelitian dapat disimpulkan bahwa dilihat dari nilai signifikansi thitung pengetahuan sebesar 0,3 lebih besar dari 0,05 (sig. $X_{1}>0,05$ ). Dengan demikian Pengetahuan tidak berpengaruh positif dan signifikan terhadap minat bertransaksi menggunakan Fintech. Dilihat dari nilai signifikansi $t_{\text {hitung }}$ Kemudahan sebesar 0,02 lebih kecil dari 0,05 (sig. $\mathrm{X}_{2}<0,05$ ). Dengan demikian dapat dinyatakan Kemudahan berpengaruh positif dan signifikan terhadap minat bertransaksi menggunakan Fintech. Dilihat dari nilai signifikansi thitung risiko sebesar 0,00 lebih kecil dari 0,05 (sig. $X_{3}<0,05$ ) dan nilai koefisien beta bertanda negatif. Dengan demikian Risiko berpengaruh negatif dan signifikan terhadap minat bertransaski menggunakan Fintech. Dilihat dari nilai $\mathrm{R}^{2}$ sebesar 0,328 maka dapat dinyatakan bahwa pengetahuan, kemudahan dan risiko berpengaruh terhadap minat bertransaksi menggunakan Fintech secara bersamasama sebesar 32,8\%.

\section{Daftar Pustaka}

A,Paul,P. "Consumer Acceptance of Electronic Commerce: Integrating, Trust and Risk with the Technology

52 Muhammad Wildan, pengaruh persepsi Kemudahan Penggunaan, 2018.
Acceptance Mode". International Journal of Electronic Commerce, Vol.7.

Adhitama, Paulus, Faktor-Faktor yang Mempengaruhi Minat Berwiarausaha, Jurnal Fakultas Ekonomi Universitas Diponegoro.

Amaerita,Alvani H dan Sariguna, Posma J.K, Financial Technology, Regulasi dan Adaptasi Perbankan di Indonesia.Vol $\quad 3, \quad$ No.1 (2018).ejournal.uki.ac.id (diakses 26 November 2019)

Amer, Douglas Et.al, "The Evolution of Fintech : A new Post-crisis Paradigm?",Research Paper No.2015/047, University of Hong Kong Faculty of Law, 2015.

Bank Indonesia, Surat edaran No.18/22/DKSP "Penyelenggara Layanan Keuangan Digital" 2016.

Daksi, Kamus Besar Bahasa Indonesia Pusat Bahasa, Ed 4, Jakarta : PT Gramedia Pustaka Utama,2008.

Dokumentasi diperoleh Bidang Akademik Mahasiswa (AKMAH) Fakultas Ekonomi dan Bisnis Islam pada tanggal 14 novembre 2019.

Dwi, Panggih, I (2014)." Analisis Pengaruh Persepsi Manfaat, Kemudahan Penggunaan dan Kredibilitas terhadap Minat Penggunaan Berulang Internet Banking dengan Sikap Penggunaan Sebagai Variabel Intervening". Skripsi FEBI UNDIP Semarang.

Eriyanto, Teknik Sampling Analisis Opini

Publik, (Yogyakarta: LKis, 2007).

Financial Technology, Situs Otoritas Jasa

Keuangan.

Website:

https://www.ojk.go.id (diakses 30 September 2019)

Ghozali, Imam, Aplikasi Analisis Nultivariate dengan Program IBM

e-ISSN: 2686-6633 
SPSS 21.Cet. VII, Semarang: Badan Penerbit UNDIP, 2013.

Indrawan, Rully dan Yaniawati, Poppy, Metode Penelitian. Cet.1, Bandung : PT. Rafika Adiatama, 2014.

Made, I, W, Metodologi Penelitian Sosial Ekonomi, Ed. 1, Yogyakarta: ANDI, 2006.

Marzuki, M., \& Nurdin, N. (2020). The Influence of Halal Product Expectation, Social Environment, and Fiqih Knowledge on Intention to Use Shariah Financial Technology Products. International Journal of Innovation, Creativity and Change, 13(1), 171193.

Mustofa abdul karim (2017). "Pengaruh Sistem Pembayaran Go-pay Menggunakan TAM (Technology Acceptence Model) Terhadap Intensitas penggunaan Layanan Gojek". Skripsi FE UII.

Nurdin, Muhammad, Kiat Menjadi Guru Profesional, Cet I, Yogyakarta: Prismasophie,, 2004. Pendidikan, (Cet ke-1,Yogyakarta : Deepulish, 2014).

Nurdin, N., Pettalongi, S. S., \& Yusuf, K. (2018). Knowledge Management Model in Syariah Banking. 2018 5 th International Conference on Information Technology, Computer, and Electrical Engineering (ICITACEE)

Nurdin, N. (2019). Knowledge Integration Strategy in Islamic Banks. In A. Helena \& S. Bernardete (Eds.), The Role of Knowledge Transfer in Open Innovation (pp. 118-138). IGI Global.

https:/ / doi.org/10.4018/978-15225-5849-1.ch006
Nurdin, N., Musyawarah, I., Nurfitriani, N., \& Jalil, A. (2020). Pengaruh Pelayanan Mobile Banking Terhadap Kepuasan Nasabah (Studi Pada Mahasiswa Perbankan Syariah IAIN Palu) Jurnal Ilmu Perbankan dan Keuangan Syariah, 2(2), 87-104.

Nurdin, N., \& Yusuf, K. (2020). Knowledge management lifecycle in Islamic bank: the case of syariah banks in Indonesia. International Journal of Knowledge Management Studies, 11(1), 59-80. https:/ / doi.org/10.1504/ijkms.20 20.105073

Penetrasi Pengguna Internet, Situs Asosiasi Penyelenggara Jasa Internet Indonesia. Website: htps://www.apji.or.id (diakses 29 September 2019)

Prasetyo, Bambang dan Miftahul, Lina J, Metode Penelitian Kuantitatif : Teori dan Aplikasi, Ed 1,(Jakarta : PT Raja Grafindo Persada,2006).

Riduan, Adnun Rusyana, dan Enas, Cara Mudah Belajar SPSS 17,0 dan Aplikasi Statistik Penelitian . Cet III, Bandung: Alfabeta, 2013.

Riduan, Penelitian Untuk Guru, Karyawan dan Penelitian Pemula,. Bandung: Alfabeta, 2012.

Romario dan Kholid Mukhammad, "Pengaruh Prodct Knowledge Terhadap Purchase Intention (Survei pada Pengunjung Toko Buku UB Press, Kota Malang)" Jurnal Administrasi Bisnis (JAB)|Vol. 55 No. 3 Februari 2018.

Saipul, Asep, H dan E Baharudidin, Metode Penelitian Kuantitatif Aplikasi Dalam

Sakinah , Pengaruh Bauran Pemasaran Keputusan Membeli Kartu

e-ISSN: 2686-6633 
Prabayar Produk Telkomsel Pada Mahasiswa IAIN Palu, Skripsi tidak diterbitkan (Palu: IAIN 2014).

Salma, Dewi P, Mozaik Teknologi Pendidikan E-Learning,Jakarta : PT Fajar Interpratama Mandiri, 2103.

Sarjono, Haryadi dan Julianti, Wilda, SPSS vs LISREL Sebuah Pengantar, Aplikasi Untuk Riset.Jakarta: Salemba Empat, 2011.

Siregar, Sofyan, Statistik Deskriptif untuk Penelitian Dilengkapi Perhitungan Manual dan Aplikasi SPSS Versi 17. Ed. 1, Cet. 5, Jakarta : Rajawali Pers, 2016.

Siregar, Sofyan. Metode Penelitian Kuantitatif (dilengkapi dengan perbandingan perhitungan manual dan SPSS).Jakarta: Kencana, 2013

Soekidjo, Notoadmodjo, Metode Penelitian Kesehatan, edisi revisi. Jakarta:Rinneka cipta, 2010.

Strategi Nasional Keuangan Inklusif, Situs Badan Perencanaan Pembangunan Nasional.

Website:bappenas.go.id.

Sugiyono, Metode Penelitian Kuantitatif Kualitatif dan RED, (Bandung: Alfabeta, 2013).

Sugiyono, Statistik Untuk Penelitian, Cet ke-XXII, (Bandung: Alfabeta, 2013).

Supardi, Metode Penelitian Ekonomi dan Bisnis, UII Perss : Yogyakarta2005

Surabirta, Sumadi.(2002).Psikologi Pendidikan". PT.Grafindo Perkasa rajawali:Jakarta.

Suryani, Tatik. "Perilaku Konsumen di Era Internet: Implikasi pada Strategi Pemasaran". Yogyakarta : Graha Ilmu. 2013.

Svetlana saksonova dan Irina Kusmina Marlino,(2017). "Fintech as Financial Inovation-the possibilities and problems of Implementation".
European studies research journal, vol.XX, issue $3 A, p p$.

Tim Re Andriyanto, Yaufi. "Pengaruh Persepsi Kemudahan, Persepsi Kebermanfaatan, Persepsi Risiko dan Kepercayaan Terhadap Minat Menggunakan Rekening Ponsel (Studi Kasus Pada Nasabah CIMB NIAGA Daerah Istimewa Yogyakarta)".Skripsi.Fakultas

Ekonomi Universitas Negeri Yogyakarta.2014. h.43. Nasution, dan Fahmi Natigor, Penggunaan Teknologi Informasi berdasarkan Aspek Prilaku, Universitas Sumatra Utara Digital Library, 2004.

Tim Redaksi, Kamus Besar Bahasa Indonesia Pusat Bahasa, Ed 4, Jakarta : PT Gramedia Pustaka Utama, Cet.ke,2008.

Universitas Islam Negeri Walisongo Semarang 2019).

Walgito Bimo. (1981)."Pengantar Psikologi Umum". Yogyakarta : Yayasan Penerbitan Fakultas Psikologi UGM.

Wildan, Muhammad," Pengaruh Persepsi Kemudahan Penggunaan, Efektivitas dan Risiko Terhadap Minat Bertransaksi Menggunakan Financial Technology (Fintech) pada Mahasiswa FEBI " Skripsi UIN Walisongo Semarang.2018.

Yaufi, Andriyanto. "Pengaruh Persepsi Kemudahan, Persepsi Kebermanfaatan, Persepsi Risiko dan Kepercayaan Terhadap Minat Menggunakan Rekening Ponsel (Studi Kasus Pada Nasabah CIMB NIAGA Daerah Istimewa

Yogyakarta)".Skripsi.Fakultas Ekonomi Universitas Negeri Yogyakarta.2014. 
Yusuf Fitra Mulyana. "Pengaruh Kepercayaan, Persepsi Risiko dan Keamanan Terhadap Minat Beli Konsumen Pada Toko Online". Skipsi, FE UNDIP, Semarang. 2016.

e-ISSN: $2686-6633$ 